\title{
Green Synthesis of Reduced Graphene Oxide and Device Fabrication for Optoelectronic Applications
}

\author{
Elif Daş*(i) \\ Ataturk University, Faculty of Science, Department of Physics, 25240, Erzurum, Turkey
}

Geliş / Received: 19/04/2021, Kabul / Accepted: 27/04/2021

\begin{abstract}
Graphene is thought to be an outstanding material for novel photoelectrical devices due to its unique properties. However, because of the atomic thickness of the interaction lenght between graphene and light, the performance of graphene-based photoelectrical devices is limited. Therefore, in this presented study, graphene derivatives such as graphene oxide (GO) and reduced graphene oxide (rGO) were used instead of graphene to enhance the light absorption for metal-interlayer-semiconductor type Schottky heterojunction fabrication. Firstly, GO synthesis was made by the modified Hummer method, then rGO synthesis was carried out via the chemical reduction method by using L-ascorbic acid (LAA) as a reducing agent. The surface morphology, chemical compositions and optical properties of the synthesized materials were characterized using SEM-EDS, and UVVis-NIR spectrophotometer analyses. Subsequently, GO/n-Si and rGO/n-Si heterojunction device fabrications were made by using the spin coating method. The main junction parameters of the fabricated devices were determined using current-voltage (I-V) measurements. The obtained results indicate that the rGO thin film layer has a significant impact on the I-V characteristics due to its improved characteristics compared to the GO thin film. For this reason, I-V measurements of the $\mathrm{rGO} / \mathrm{n}-\mathrm{Si}$ heterojunction device were have been investigated as a function of temperature. The results revealed that the ideality factor $(n)$, and series resistance $\left(R_{s}\right)$ increased by the decreasing temperature while the barrier height $(\Phi b)$ decreases. Furthermore, I-V measurements of the $\mathrm{rGO} / \mathrm{n}-\mathrm{Si}$ heterojunction device were performed under light illumination at room temperature. The obtained results showed that the synthesized rGO material can be used in optoelectronic applications such as photodiodes and photodetectors.
\end{abstract}

Keywords: L-ascorbic acid, reduced graphene oxide, optoelectronic devices, n-Si

\section{İndirgenmiş Grafen Oksitin Yeşil Sentezi ve Optoelektronik Uygulamalar için Aygıt Fabrikasyonu}

\section{$\ddot{O} \mathbf{z}$}

Grafen, benzersiz özelliklerinden dolayı yeni geliştirilen fotoelekrik aygıtlar için olağanüstü bir malzeme olarak düşünülmektedir. Fakat, grafen tabanlı fotoelektrik cihazların performansı, grafen ve 1şık arasındaki etkileşim uzunluğunun atomik kalınlığı nedeniyle sınırlıdır. $\mathrm{Bu}$ nedenle, sunulan bu çalışmada, metal-arayüzeyyarıiletken tipi Schottky heteroeklem üretimi için 1şık absorpsiyonunu arttırmak adına grafen yerine grafen oksit (GO) ve indirgenmiş grafen oksit (rGO) gibi grafen türevleri kullanılmıştır. İlk olarak, modifiye Hummer yöntemi ile GO sentezi, daha sonra indirgeyici ajan L-askorbik asit (LAA) kullanılarak kimyasal indirgeme yöntemi ile rGO sentezi gerçekleştirildi. Sentezlenen malzemelerin yüzey morfolojileri, kimyasal bileşimleri ve optik özellikleri SEM-EDS ve UV-Vis-NIR spektrofotometre analizleri kullanılarak karakterize edildi. Ardından, spin kaplama yöntemi kullanılarak GO/n-Si ve rGO/n-Si heteroeklem aygıtlarının fabrikasyonu

*Corresponding Author: das.elif@gmail.com 
yapıldı. Fabrikasyonu gerçekleştirilen aygıtların karateristik eklem parametreleri akım-voltaj (I-V) ölçümleri kullanılarak tayin edildi. Elde edilen sonuçlar, rGO ince film tabakasının, GO ince film tabakasına kıyasla sahip olduğu geliştirilmiş özellikleri nedeniyle I-V karakteristikleri üzerinde önemli bir etkiye sahip olduğunu göstermektedir. Bu nedenle, rGO/n-Si heteroeklem aygıtının I-V ölçümleri sıcaklığın bir fonksiyonu olarak da incelenmiştir. Sonuçlar, idealite faktörünün $(n)$ ve seri direncin $\left(R_{s}\right)$ artan sıcaklıkla arttı̆̆ını, bariyer yüksekliğinin $(\Phi b)$ azaldığını ortaya koymaktadır. Ayrıca, oda sıcaklığında ışık aydınlatması altında rGO/n-Si heteroeklem aygıtının I-V ölçümleri de gerçekleştirilmiştir. Elde edilen sonuçlar sentezlenen rGO malzemesinin fotodiyotlar ve fotodedektörler gibi optoelektronik uygulamalarda kullanılabileceğini göstermektedir.

Anahtar Kelimeler: L-askorbik asit, indirgenmiş grafen oksit, optoelektronik aygıtlar, n-Si

\section{Introduction}

Optoelectronic devices are widely used in many aspects of modern life, from simple household appliances to medical instruments. For this reason, intensive studies are carried out on the development of optoelectronic devices. In recent years, various optoelectronic devices with innovative materials have been reported (A et al., 2020; Asare et al., 2020). Graphene is also one of those innovative materials and it is defined as the material made of a single layer of carbon atoms distributed in the vertexes of a hexagonal network (Daş et al., 2016; Choi et al., 2020). Graphene possesses unique physical properties that are hardly seen in traditional semiconductors, which arouses tremendous interest in both scientists and engineers. These excellent properties of graphene enable it to be used in many different applications (Choi et al., 2010; Chang and Wu, 2013; Hur and Park, 2013). However, the zero-band gap electronic structure of graphene limits its use as an active material for various optoelectronic applications (Liu et al., 2015; Kim, 2018). In theory, a single layer of graphene absorbs approximately 2.3\% of light regardless of wavelength. Moreover, it has been experimentally demonstrated on suspended exfoliated graphene by Nair et al. (2008), where each graphene layer absorbs $\sim 2.3 \%$ of incident light regardless of wavelength in the visible spectrum $(400-750 \mathrm{~nm})$. Therefore, graphene cannot be used effectively for any emission-based optoelectronic applications. According to literature reports, this issue can be solved by using graphene derivatives such as graphene oxide (GO) or reduced graphene oxide (rGO) (Bhaumik and Narayan, 2019). GO is an atomically thin sheet of carbon covalently bonded to functional groups containing oxygen. So, it contains $\mathrm{sp}^{2}$ and $\mathrm{sp}^{3}$ hybridized carbon atoms (Yurtcan and Daş, 2018). Generally, it is used as a precursor material for the synthesis of rGO, however, it has attracted considerable attention due to its optical properties. Also, unlike graphene, GO is water-soluble which allows its direct deposition from aqueous suspension for device applications. But, GO is electrically insulating and needs further processing to be used as a conductive material (Stankovich et al., 2007). According to the literature reports, GO can be converted to its electrically variant, rGO, through a variety of reduction approaches such as chemical, thermal, hydrothermal, photothermal and electrochemical (Gao and Duan, 2014). Also, the degree of conductivity of rGO is dependent on the reduction method used.

The chemical reduction of GO is one of the hottest topics in GO research, and many synthesis procedures with different reagents have been developed so far (Chua and Pumera, 2014). However, most of these procedures often require hazardous reducing agents and complicated chemical process (Mao et al., 2012; Rabchinskii et al., 2018). For these reasons, it is very important to develop a low-cost, easy and efficient approach for preparing soluble rGO sheets in large quantities. To date, scientists have done a lot based on L- ascorbic acid (LAA) assisted reduction, and have testified that LAA is an alternative reductant compared to hazardous reducing agents such as hydrazine (Ha et al., 2012, Zhu et al., 2012). Moreover, physical 
properties of LAA such as electrical conductivity have been shown to be better or similar to hydrazine-reduced GO (De Silva et al., 2017; Iskandar et al., 2017). On the other hand, it has been shown that rGO reduced by LAA can be employed in different scenarios, including biomedical, sensors and coating solar energy (Dua et al., 2010; Sui et al. 2011, Ding et al., 2015). It was also reported by M. J. et. al. (2010) that LAA was the first innocuous and safe reductant. In the light of these presented reports, in this study, LAA was used as the reducing agent for rGO synthesis. Subsequently, GO and rGO-semiconductor heterojunction fabrications were carried out. Even though there is a lot of research being conducted on graphene itself, the GO and rGO semiconductor heterojunction based devices are seldom studied. In this sense, I believe that this study will make an important contribution to the literature.

\section{Experimental}

\subsection{Preparation of graphite oxide and graphene oxide (GO)}

Graphite powders purchased from Alfa Aesar with an average particle size of 325 mesh were used for the preparation of bulk graphite oxide. A modified version of Hummer's method was used to oxidize graphite to graphite oxide (Hummer and Offeman, 1958). Briefly, $0.25 \mathrm{~g}$ of natural graphite powder and $0.125 \mathrm{~g}$ of $\mathrm{NaNO}_{3}$ were added to $5.75 \mathrm{~mL}$ of $\mathrm{H}_{2} \mathrm{SO}_{4}$ under stirring in a flask that had been cooled to $0^{\circ} \mathrm{C}$ using an ice bath. Next, $0.75 \mathrm{~g}$ of $\mathrm{KMnO}_{4}$ was added slowly to the flask keeping the temperature below $20^{\circ} \mathrm{C}$. Subsequently, the ice bath was removed and the flask was heated to $35^{\circ} \mathrm{C}$ and maintained at this temperature for $30 \mathrm{~min}$, followed by the slow addition of $11.5 \mathrm{~mL}$ of deionized (DI) water (Note: Caution must be exercised since this is a highly exothermic process). The temperature of the reaction mixture increased to $\sim 98^{\circ} \mathrm{C}$ upon the addition of water and the reaction vessel was maintained at this temperature for $15 \mathrm{~min}$. Next, the suspension was further diluted with $34 \mathrm{~mL}$ of water and treated with $3 \% \mathrm{H}_{2} \mathrm{O}_{2}$ until the cessation of gas evolution. Finally, the suspension was vacuum filtered and left to dry under vacuum overnight after washing with copious amounts of $\mathrm{DI}_{2} \mathrm{O}$. The solid graphite oxide thus obtained was then exfoliated in DI water by ultrasonication for 2 $\mathrm{h}$ to form a GO suspension with a concentration of $\sim 1 \mathrm{mg} / \mathrm{mL}$. A homogeneous light yellowbrown solution was obtained after ultrasonication and was used for deposition without any additional process.

\subsection{Preparation of reduced graphene oxide (rGO)}

The modified method prescribed by Fernandez-Merino et al. (2010) was applied in order to the preparation of rGO. Firstly, $1.0 \mathrm{~g}$ graphene oxide was added to $900 \mathrm{~mL}$ of DI water and sonicated until dispersed. The $\mathrm{pH}$ of the pale-yellow graphene oxide solution was adjusted to 12 with $1 \mathrm{M} \mathrm{NaOH}$ and the solution was heated to $95{ }^{\circ} \mathrm{C}$ on an isotemp hotplate with temperature probe. $9.0 \mathrm{~g}$ of LAA was added to $100 \mathrm{~mL}$ of DI water and sonicated until dispersed. The LAA was added to the basic GO solution and allowed to react for 1 hour at 95 ${ }^{\circ} \mathrm{C}$. During the reaction, the $\mathrm{pH}$ of the solution was monitored and maintained at 12 via the addition of $1 \mathrm{M} \mathrm{NaOH}$. After removal of the heat, the solution was cooled to room temperature and filtered through filter paper. The remaining black precipitate was washed five times with $200 \mathrm{~mL}$ DI water to remove any residual LAA, each time fully dispersing the black precipitate in solution. Once clean of LAA, the material was vacuum dried overnight at room temperature.

\subsection{Device Fabrication Process}

Si semiconductor wafer (doped with phosphorus) with (100) orientation, $0.4 \mathrm{~mm}$ thickness and 1-10 $\Omega \mathrm{cm}$ resistivity were used for GO based heterojunction device fabrication. The $\mathrm{n}$-Si wafer 
was firstly cleaned by using the well known a cleaning procedure (Çaldıran et al., 2013). Then, the ohmic contact was made by depositing aluminum (Al) films on the back surface of the $\mathrm{Si}$ substrate. The wafer was annealed at $450{ }^{\circ} \mathrm{C}$ for $3 \mathrm{~min}$ in an inert atmosphere. After that, the exfoliated GO and rGO materials were coated onto the front surface of the Si wafer by spin coating method (at $1000 \mathrm{rpm}, 60 \mathrm{~s}$ ). At this stage, GO and rGO nanomaterials were dissolved in DI water to make $5 \mathrm{mg} / 5 \mathrm{ml}$ solution. After the coating process, the Si wafers were left overnight at room temperature. Finally, gold $\mathrm{Au}$ ) electrode contacts were made on the thin film layer by using a shadow mask made from aluminum foil. Fig. 1 shows the schematic illustration of the prepared $\mathrm{Au} / \mathrm{GO} / \mathrm{n}-\mathrm{Si} / \mathrm{Al}$ and $\mathrm{Au} / \mathrm{rGO} / \mathrm{n}-\mathrm{Si} / \mathrm{Al}$ heterojunctions.

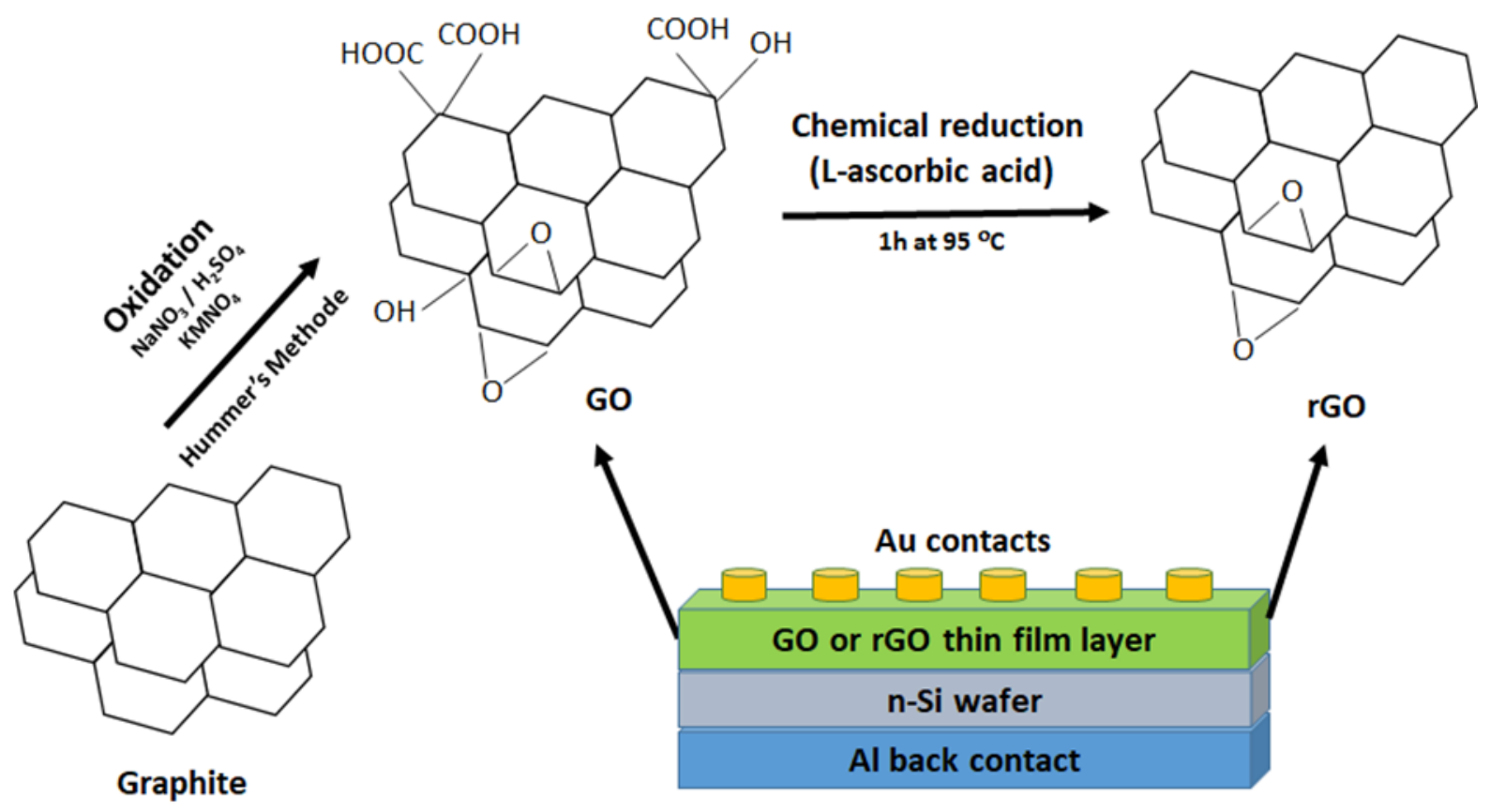

$\mathrm{GO} / \mathrm{n}-\mathrm{Si}$ and $\mathrm{rGO} / \mathrm{n}-\mathrm{Si}$

Fig. 1. The schematic illustration of the prepared GO/n-Si and $\mathrm{rGO} / \mathrm{n}-\mathrm{Si}$ heterojunction devices.

\subsection{Measurements}

In order to determine the physical properties of the syntesized materials, Zeiss Sigma 300 brand scanning electron microscope (SEM) and Shimadzu UV-3600 Plus brand UV-Vis-NIR spectrophotometer were used. In addition, to calculate the some electrical parameters of the fabricated devices, the current-voltage (I-V) and capacitance-voltage $(\mathrm{C}-\mathrm{V})$ measurements were performed using a computer-interfaced Keithley 2400 source-meter and HP 4192A LF impedance-analyzer, respectively. All electrical measurements were conducted in the ambient atmosphere at room temperature apart from the temperature dependent measurements. Additionally, the I-V measurements under light were carried out by a Sciencetech solar simulator SF300 (AM1.5 G) with a Keithley 2400 at $100 \mathrm{mWcm}^{-2}$ power. 


\section{Results and Discussion}

\subsection{Physical Properties of the Synthesized Materials}

The surface morphology and chemical composition of the synthesized graphite oxide and rGO materials were studied using a scanning electron microscope equipped with an X-ray energy dispersive spectrometer (EDS) unit. The obtained SEM plan-view images of the materials and the corresponding EDS results were given in Fig. 2 and Table 1, respectively. As shown in the figure, it is clearly seen that a thin layer of graphite oxide with some wrinkles and slightly curved structure has been achieved, while rGO sheets show a more crumpled and overlapped multilayer surface structure (Chen et al., 2017). This change in the morphology between graphite oxide and rGO could be due to the formation and reconstruction of new chemical bonds on the few-layered carbon (Song et al., 2012). The C:O ratio of graphite oxide and rGO materials was also examined using the EDS mesurements (Table 1). The C:O ratio in graphite oxide, and rGO was 1.61 , and 6.03 , respectively. The increase in $\mathrm{C}: \mathrm{O}$ ratio implied that $\mathrm{rGO}$ was succesfully produced using LAA reduction process. As graphite oxide is the most oxidized form of graphite, therefore, its $\mathrm{C}: \mathrm{O}$ ratio is low due to high oxygen content, whereas in $\mathrm{rGO}$, much of the oxygen content decreased and its $\mathrm{C}: \mathrm{O}$ ratio is larger. So, the EDS results confirms the conversion of graphite oxide to rGO.
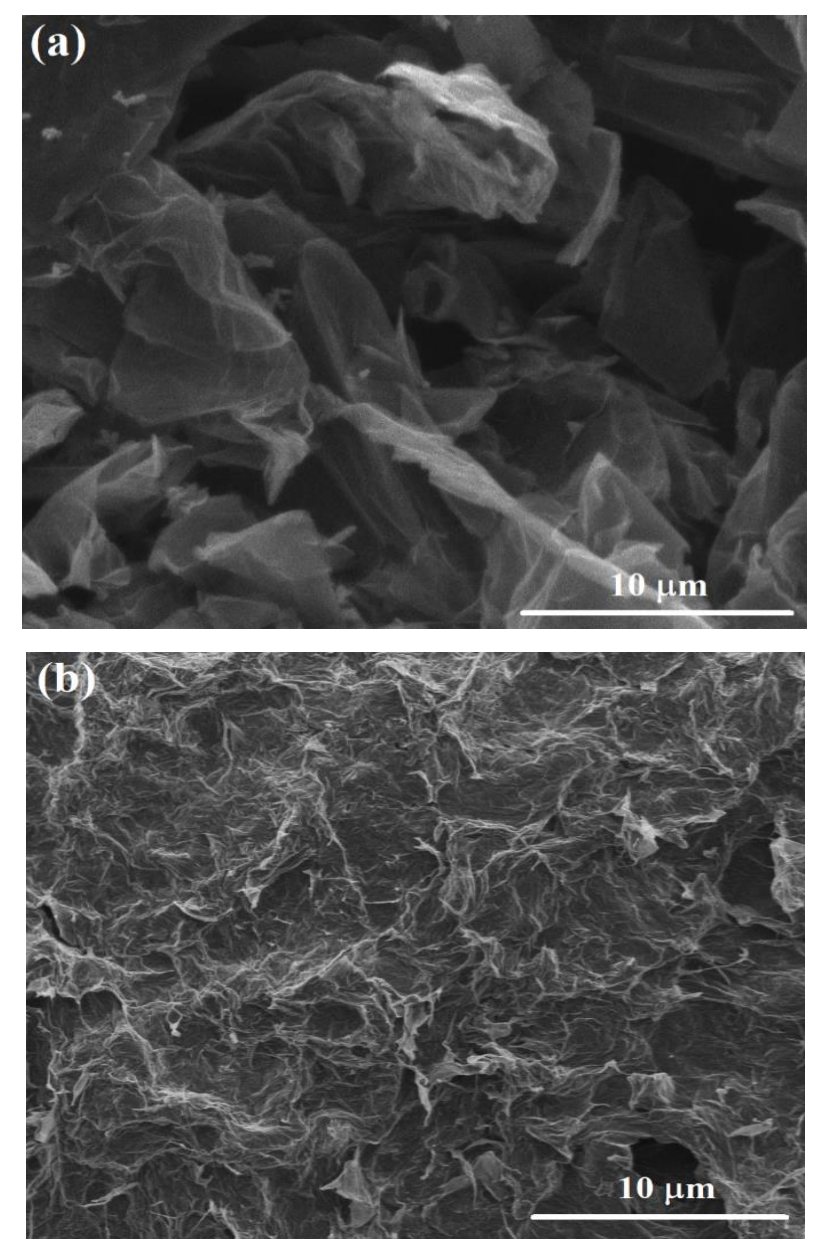

Fig. 2. SEM images of the (a) graphite oxide and (b) rGO materials. 
Table 1. Chemical composition of the graphite oxide and rGO materials obtained from EDS analysis.

\begin{tabular}{|c|c|c|c|c|c|c|c|}
\hline \multirow{2}{*}{ Sample } & \multicolumn{6}{|c|}{ Elemental Composition (at \%) } & \multirow[b]{2}{*}{$\begin{array}{l}\mathrm{C} / \mathrm{O} \\
\text { ratio }\end{array}$} \\
\hline & $\mathbf{C}$ & $\mathbf{O}$ & $\mathbf{S}$ & $\mathbf{N a}$ & Mn & $\mathbf{K}$ & \\
\hline $\begin{array}{c}\text { Graphite } \\
\text { Oxide }\end{array}$ & 45.32 & 28.18 & 13.52 & 2.89 & 5.42 & 4.67 & 1.61 \\
\hline rGO & 85.77 & 14.23 & - & - & - & - & 6.03 \\
\hline
\end{tabular}

In addition, the GO and rGO materials were further confirmed by UV-visible absorption spectroscopy. Fig. 3 shows the optical absorption spectras of the GO and rGO materials. GO exhibits two absorption peaks at $230 \mathrm{~nm}$, and a shoulder peak at $306 \mathrm{~nm}$, which are attributed to the $\pi-\pi^{*}$ transitions of $\mathrm{C}-\mathrm{C}$, and $\mathrm{n}-\pi^{*}$ transitions of $\mathrm{C}=\mathrm{O}$ bonds, respectively (Tiamduangtawan and Saenboonruand, 2019). The absorption peak observed at $230 \mathrm{~nm}$ of GO has been shifted to $270 \mathrm{~nm}$ for rGO, suggesting that the electronic conjugation of the aromatic structure might be restored (Andrijanto et al., 2016). The observed features of these spectra and their absorption peak are similar to those of GO and rGO reported in the literature (Zheng et al., 2015), where the optical band gap of the GO and rGO materials was found to be $4.2 \mathrm{eV}$ and $3.5 \mathrm{eV}$, respectively.

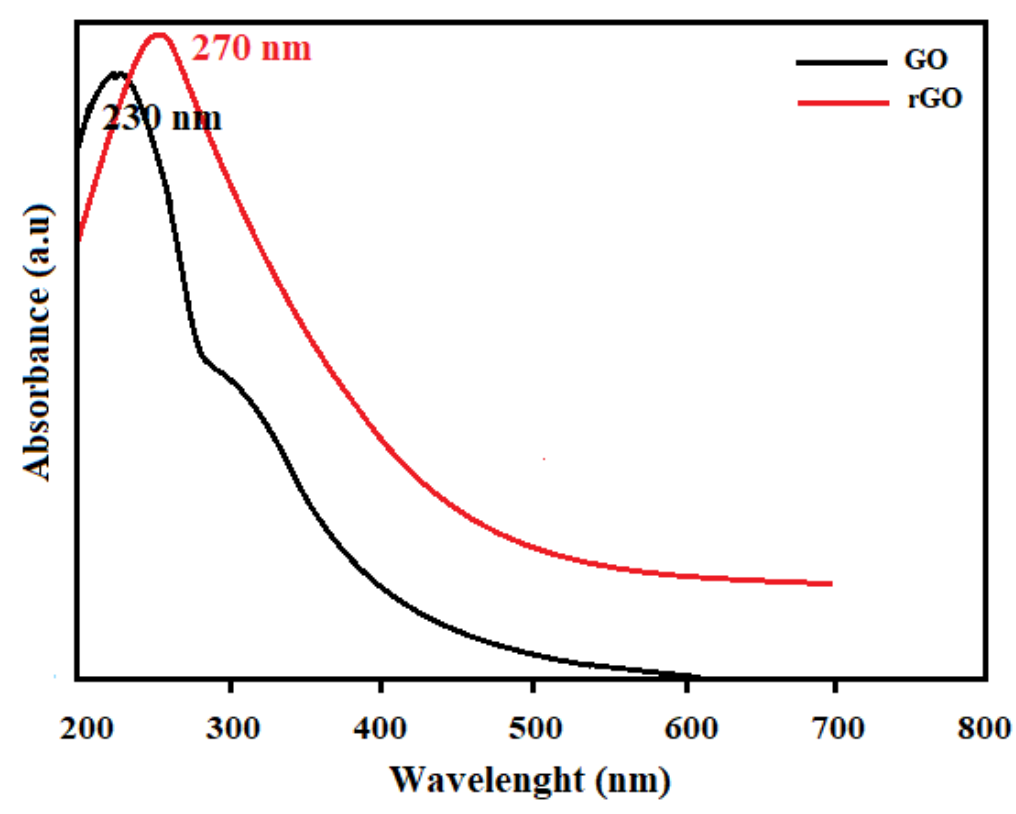

Fig. 3. UV-Vis spectra of the GO and rGO materials.

\subsection{Current-Voltage (I-V) Characteristics of the GO based Heterojunction Devices}

Fig. 4 shows the measured I-V graphs of the GO/n-Si and $\mathrm{rGO} / \mathrm{n}-\mathrm{Si}$ heterojunction devices at room temperature in a dark environment. The I-V characteristics shown in the figure were obtained from a batch of 6-7 diodes of the same diameters. In the forward bias region of the $\mathrm{GO} / \mathrm{n}-\mathrm{Si}$ heterojunction device, two type of I-V characteristic were observed: (i) single barrier 
and (ii) double barrier characteristics, as shown in Fig. 4 (a). However, the majority of the diodes show single barrier characteristics. On the other hand, the observed double barrier characteristics (@ low bias levels) across the wafer can be attributed to interface anomaly with a non-uniform spatial distribution, such as surface and bulk crystal defects, as was also pointed out by Im et al. (2001). In case of the rGO/n-Si heterojunction device (Fig. 4 (b)), the obtained $\mathrm{I}-\mathrm{V}$ characteristics exhibit single barrier properties. This type of curve was also observed for the $\mathrm{rGO} / \mathrm{n}$-Si device structure in our previous study presented by our research group (Daş et al., 2021).
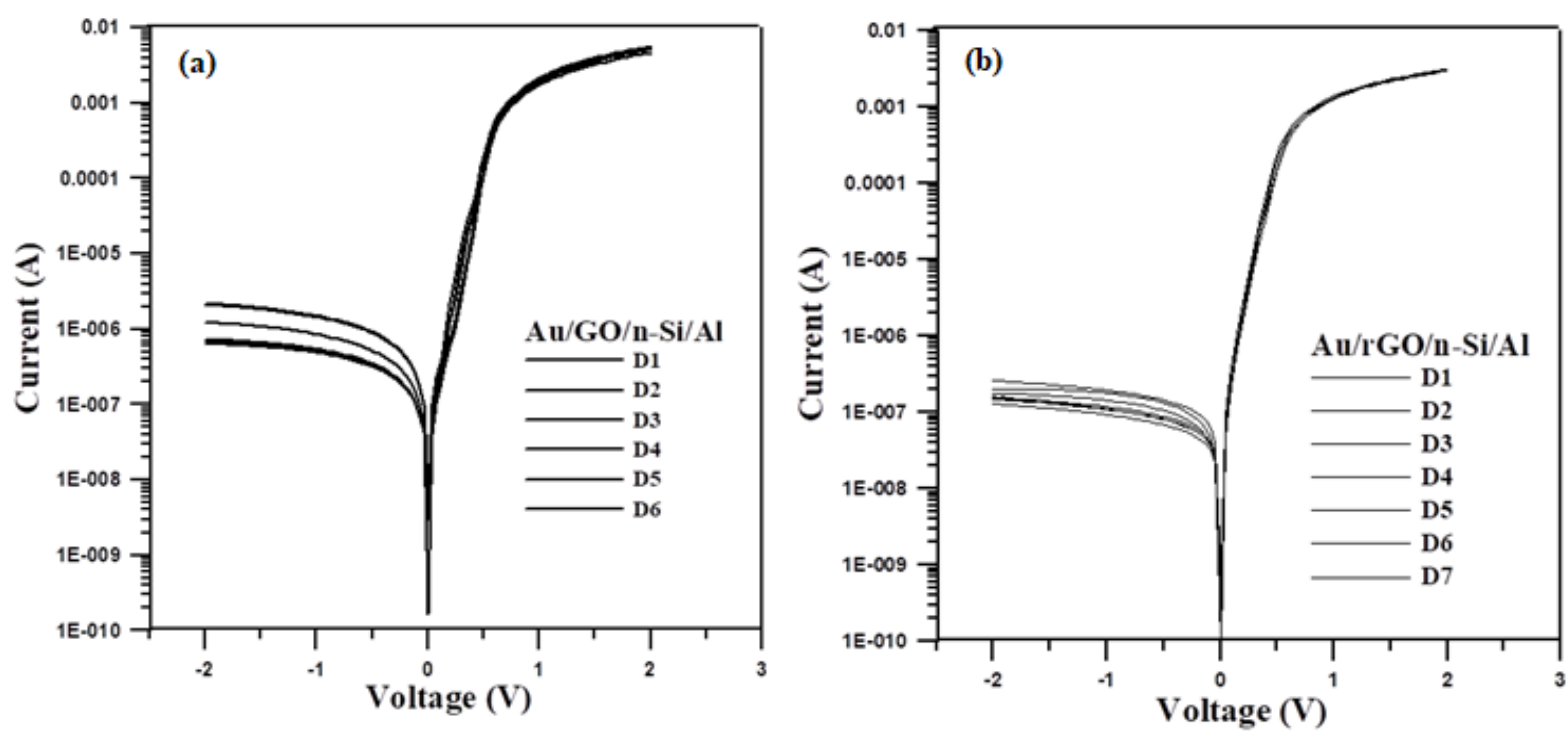

Fig. 4. The I-V characteristics of the (a) GO/n-Si and (b) rGO/n-Si heterojunction devices at room temperature.

According to the literature reports, the current transport mechanism in the heterojunction devices is generally analyzed using the Thermionic Emission (TE) theory given below (Orhan et al., 2020).

$I=I_{o}\left[\exp \left(\frac{q V}{n k T}\right)-1\right]$

where $I_{0}$ is the saturation current given by

$I_{o}=A A^{*} T^{2} \exp \left(-q \Phi_{b} / k T\right)$

$\mathrm{q}$ is the electron charge, $\mathrm{V}$ is the forward-bias voltage, $\mathrm{A}$ is the effective diode area, $\mathrm{k}$ is the Boltzmann constant, $\mathrm{T}$ is the temperature (in Kelvin), $\mathrm{A}^{*}$ is the effective Richardson constant of semiconductor and its equal to $112 \mathrm{Acm}^{-2} \mathrm{~K}^{-2}$ for $\mathrm{n}$-type $\mathrm{Si}, \Phi_{\mathrm{b}}$ is the effective barrier height at zero bias and $\mathrm{n}$ is the ideality factor. The ideality factor is calculated from the slope of the forward I-V characteristics through the relation:

$n=\frac{q}{k T}\left(\frac{d V}{d \ln I}\right)$

and the value of the barrier hight is determined as: 
$\Phi_{b}=\frac{k T}{q} \ln \left(\frac{A A^{*} T^{2}}{I_{0}}\right)$

In the light of this information, the $\mathrm{n}, \Phi \mathrm{b}$, and $\mathrm{I}_{\mathrm{o}}$ values of the fabricated devices were calculated and the results were given in Table 2. As can be seen in Table 2, rGO thin film layer has a significant impact on the I-V characteristics due to its improved characteristics compared to the GO thin film. Therefore, in this study, the device properties of $\mathrm{rGO} / \mathrm{n}$-Si heterojunction were studied in detail.

Table 2. Some electrical parameters of the GO/n-Si and $\mathrm{rGO} / \mathrm{n}-\mathrm{Si}$ heterojunction device.

\begin{tabular}{cccc|cccc}
\hline & \multicolumn{3}{c}{ GO/n-Si } & \multicolumn{5}{c}{ rGO/n-Si } \\
\hline & $\mathbf{n}$ & $\mathbf{\Phi b}(\mathbf{e V})$ & $\mathbf{I}_{\mathbf{0}}(\mathbf{A})$ & & $\mathbf{n}$ & $\mathbf{\Phi b}(\mathbf{e V})$ & $\mathbf{I}_{\mathbf{o}}(\mathbf{A})$ \\
\hline D1 & 2.42 & 0.74 & $2.90^{*} 10^{-8}$ & D1 & 1.55 & 0.74 & $3.46^{*} 10^{-8}$ \\
D2 & 1.79 & 0.79 & $3.71 * 10^{-9}$ & D2 & 1.48 & 0.75 & $2.21 * 10^{-8}$ \\
D3 & 2.16 & 0.74 & $2.80 * 10^{-8}$ & D3 & 1.47 & 0.75 & $2.05^{*} 10^{-8}$ \\
D4 & 2.18 & 0.76 & $1.32 * 10^{-8}$ & D4 & 1.47 & 0.75 & $2.08 * 10^{-8}$ \\
D5 & 1.98 & 0.74 & $2.44 * 10^{-8}$ & D5 & 1.45 & 0.75 & $1.89 * 10^{-8}$ \\
D6 & 1.79 & 0.74 & $2.88 * 10^{-8}$ & D6 & 1.53 & 0.75 & $1.98 * 10^{-8}$ \\
& & & & D7 & 1.44 & 0.76 & $1.67 * 10^{-8}$ \\
\hline
\end{tabular}

In the first stage, the I-V characteristic of the $\mathrm{rGO} / \mathrm{n}$-Si heterojunction device was investigated as a function of temperature. Fig. 5. depicts the semi-logarithmic I-V characteristic curves of the $\mathrm{rGO} / \mathrm{n}$-Si heterojunction device at various temperatures. In the figure, it is seen that the fabricated device exhibited a good rectification behavior at all measured temperature values. In this sense, it could be said that the fabricated device is convenient to use in electronic applications in wide temperature ranges. On the other hand, the crucial device parameters such as $\mathrm{n}, \Phi \mathrm{b}$, and $\mathrm{I}_{\mathrm{o}}$ values for the $\mathrm{rGO} / \mathrm{n}-\mathrm{Si}$ heterojunction device were also calculated from $\mathrm{I}-\mathrm{V}$ curves using TE theory and the results were tabulated in Table 3. As seen, the $n$ increases with decreasing temperature while $\Phi b$ decreases. Such higher values of $n$ and lower values of $\Phi b$ at low temperatures and vice versa, can be attributed to several reasons such as interface inhomogeneity, non-uniform distribution of the interfacial charges (Karabulut et al., 2020). 


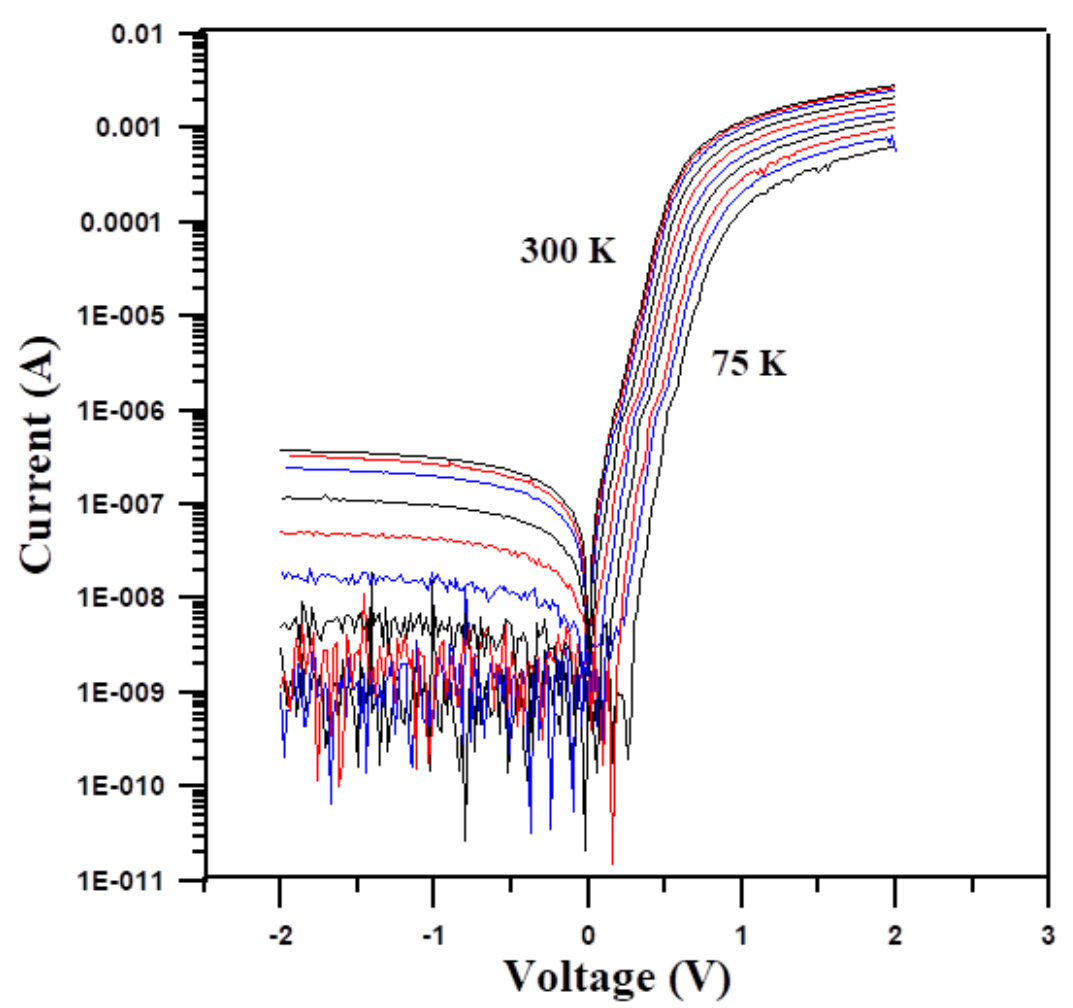

Fig. 5. The $\mathrm{I}-\mathrm{V}$ characteristics of the $\mathrm{rGO} / \mathrm{n}-\mathrm{Si}$ heterojunction device as a function of temperature in the range of $75-300 \mathrm{~K}$ with $25 \mathrm{~K}$ steps.

Table 3. The junction parameters of the $\mathrm{rGO} / \mathrm{n}-\mathrm{Si}$ heterojunction device as a function of temperature.

\begin{tabular}{cccccc}
\hline \multirow{2}{*}{$\begin{array}{c}\text { Temperature } \\
(\mathbf{K})\end{array}$} & \multicolumn{3}{c}{ TE } & \multicolumn{2}{c}{ Norde } \\
\cline { 2 - 6 } & $\mathbf{n}$ & $\mathbf{\Phi b}(\mathbf{e V})$ & $\mathbf{I} \mathbf{0}(\mathbf{A})$ & $\mathbf{\Phi b}(\mathbf{e V})$ & $\mathbf{R s}(\mathbf{\Omega})$ \\
\hline 300 & 1.44 & 0.76 & $1.67 * 10^{-8}$ & 0.76 & 71 \\
275 & 1.82 & 0.68 & $2.18^{*} 10^{-8}$ & 0.68 & 93 \\
250 & 1.94 & 0.63 & $1.38^{*} 10^{-8}$ & 0.62 & 122 \\
225 & 2.20 & 0.58 & $5.66^{*} 10^{-9}$ & 0.58 & 275 \\
200 & 2.75 & 0.52 & $3.04 * 10^{-9}$ & 0.52 & 307 \\
175 & 3.12 & 0.46 & $1.14^{*} 10^{-9}$ & 0.47 & 474 \\
150 & 3.21 & 0.42 & $2.15^{*} 10^{-10}$ & 0.42 & 926 \\
125 & 3.90 & 0.36 & $5.85^{*} 10^{-11}$ & 0.36 & 985 \\
100 & 5.25 & 0.28 & $4.37^{-11} 10^{-11}$ & 0.27 & 1327 \\
75 & 5.39 & 0.24 & $6.05^{*} 10^{-13}$ & 0.23 & 2867 \\
\hline
\end{tabular}

An important parameter that affects the performance of the electronic devices is series resistance $\left(R_{s}\right)$ and the $R_{s}$ is seen at the high voltage values of the forward bias region. The experimental series resistance can be determined by several methods. One of them is the modified Norde function (Çaldıran, 2021). The Norde function is defines as:

$$
F(V)=\frac{V}{\gamma}-\frac{k T}{q} \ln \left(\frac{I(V)}{A A^{*} T^{2}}\right)
$$


where $\gamma$ is an integer greater than the $\mathrm{n}$ and $\mathrm{I}(\mathrm{V})$ is current obtained from the $\mathrm{I}-\mathrm{V}$ curve. When the minimum of the F vs V plot is plotted, the $\Phi b$ and $R_{S}$ can be calculated using the following equations:

$\Phi_{b}=F\left(V_{\min }\right)+\frac{V_{\min }}{\gamma}-\frac{k T}{q}$

and,

$R_{s}=\frac{k T(\gamma-n)}{q I_{\min }}$

Fig. 6 shows the plot of $\mathrm{F}(\mathrm{V})$ versus of $\mathrm{V}$ of $\mathrm{rGO} / \mathrm{n}-\mathrm{Si}$ heterojunction device for different temperature values. The calculated $\Phi b$ and $R_{s}$ values by the aid of Norde function were presented in Table 3. As can be seen from the table, $\Phi b$ and $R_{s}$ are strongly temperature dependent. While the $\mathrm{R}_{\mathrm{s}}$ increases with decreasing temperature, the $\Phi b$ decreases. The decrease in $R_{S}$ with increasing temperature can be attributed to the increase in the number of charge carriers with the effect of temperature (Ertap et al., 2020). Also, it is seen that the $\Phi$ b values obtained by TE method and Norde function are in good agreement with each other.

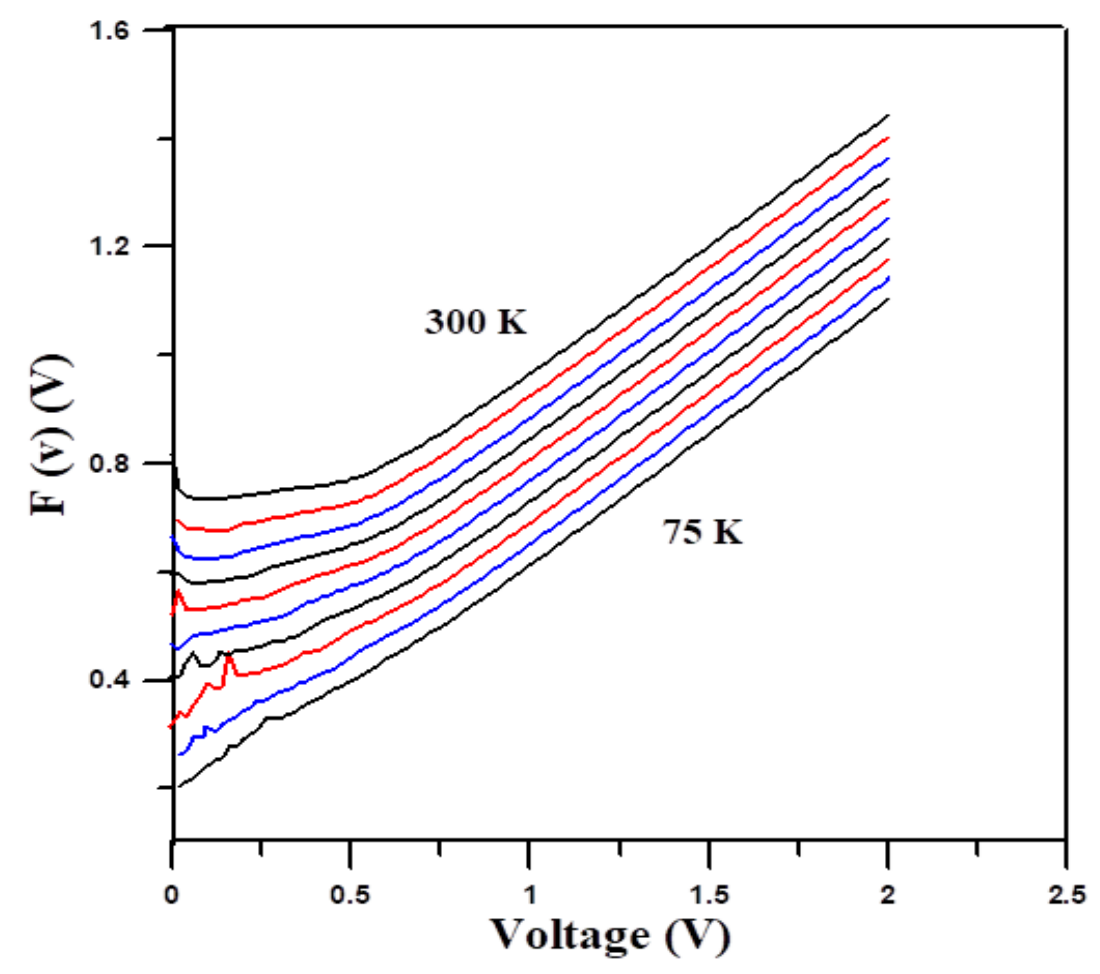

Fig. 6. $\mathrm{F}(\mathrm{V})$ vs $\mathrm{V}$ plot of the $\mathrm{rGO} / \mathrm{n}-\mathrm{Si}$ heterojunction device. 


\subsection{Photoelectrical Characteristics of rGO/n-Si Heterojunction Device}

In order to see the effect of the illumination on the performance of the $\mathrm{rGO} / \mathrm{n}$-Si heterojunction device, the I-V measurements of the device were performed in the dark and under light illumination at room temperature. As seen in Fig. 7, the structure has not only good rectifying behavior in the dark, but also has a photoresponse property. This photoresponse can be interpreted as a result of the generation of electron-hole pairs due to the absorption of light incident on the rGO layer. Therefore, it can be said that the synthesized rGO material can be used in optoelectronic applications such as photodiodes and photodetectors and so on.

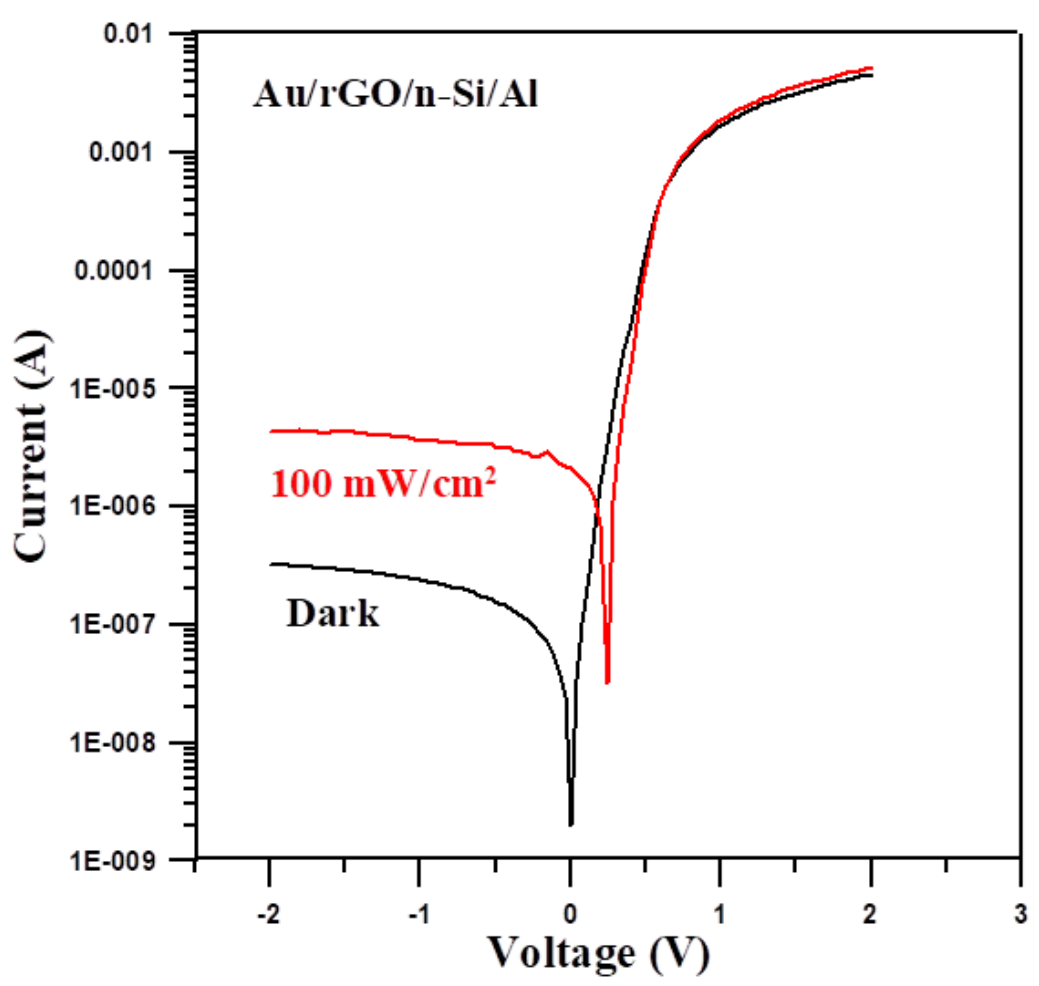

Fig. 7. Plot of I-V characteristics in dark and under illumination of $100 \mathrm{~mW} / \mathrm{cm}^{2}$ of $\mathrm{rGO} / \mathrm{n}-\mathrm{Si}$ heterojunction device.

Photoresponsivity $(\mathrm{R})$ is the most important criterion for evaluating device performance as it characterizes the photocurrent produced per unit of intensity of the illuminating light (AbdelKhalek et al., 2018). The photoresponsivity of the devices can be calculated using the following equation:

$R=\frac{I_{\text {light }}}{P_{\lambda} A}$

where $\mathrm{I}_{\text {light, }} \mathrm{P}_{\lambda}$ and $\mathrm{A}$ are the photocurrent, the intensity of illuminating light, and the effective area, respectively. For $\mathrm{rGO} / \mathrm{n}-\mathrm{Si}$ device, the responsivity toward $100 \mathrm{mWcm}^{-2}$ solar simulator light is found as $4.23 * 10^{-3} \mathrm{~A} \mathrm{~W}^{-1}$ at a reverse bias of $0.5 \mathrm{~V}$. On the other hand, the open circuit voltage $\left(\mathrm{V}_{\mathrm{oc}}\right)$ and short-circuit current $\left(\mathrm{I}_{\mathrm{sc}}\right)$ values were also determined as $0.24 \mathrm{~V}$ and $1.86 \mu \mathrm{A}$ for $\mathrm{rGO} / \mathrm{n}-\mathrm{Si}$ device, respectively. The obtained reverse current and photovoltaic values are 
typical values for optoelectronic applications as they satisfy the conditions of photodiode and photosensor (Yakuphanoğlu, 2010).

\subsection{Capacitance-Voltage (C-V) Characteristics of the rGO/n-Si Heterojunction Device}

Capacitance measurement is one of the most important non-destructive methods for obtaining information on rectifying contacts interfaces. For that reason, the $\mathrm{C}-\mathrm{V}$ characteristics of the $\mathrm{rGO} / \mathrm{n}-\mathrm{Si}$ structure as a function of the voltage at different frequencies were investigated to obtain further information about the junction properties. Fig. 8 shows the $\mathrm{C}$ vs. V plots of $\mathrm{rGO} / \mathrm{n}-\mathrm{Si}$ heterojunction device over the frequency range of $100 \mathrm{kHz}$ to $1000 \mathrm{kHz}$.

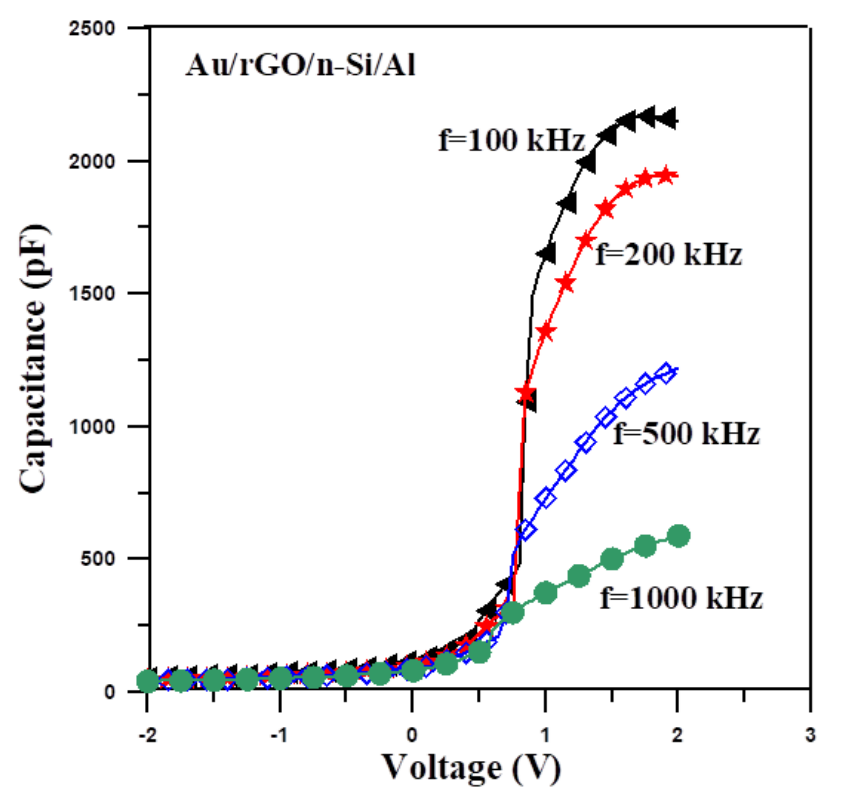

Fig. 8. The forward and the reverse bias $\mathrm{C}-\mathrm{V}$ characteristics of the $\mathrm{rGO} / \mathrm{n}-\mathrm{Si}$ heterojunction device for various frequencies.

As seen, the curve consist of three regions: inversion, depletion and accumulation layer. Among these regions, the accumulation part is the most dominant. According to the obtained results, it can be said that as the frequency increases, the capacitance decreases gradually in the accumulation region. If the frequency is increased from $100 \mathrm{kHz}$ to $1000 \mathrm{kHz}, \mathrm{n}$-type $\mathrm{Si}$ and rGO may creat electron-like surface states at the $\mathrm{rGO} / \mathrm{n}-\mathrm{Si}$ interface. These surface states reduced the accumulation of charges in the semiconductor when the positive bias is applied across the device. As a result, total capacitance of the device also decreases. Namely, the capacitance decrease with increasing frequency is due to the creation of a higher density of surface states at the interface.

In order to determine some junction parameters of the device, such as diffusion potential $\left(\mathrm{V}_{\mathrm{d}}\right.$, $\mathrm{V})$, carrier concentration $\left(\mathrm{N}_{\mathrm{d}}, \mathrm{cm}^{-3}\right)$, Fermi energy $\left(\mathrm{E}_{\mathrm{f}}, \mathrm{eV}\right)$, and $\Phi_{\mathrm{b}}(\mathrm{eV})$, the $\mathrm{C}^{-2}-\mathrm{V}$ curves were plotted as shown in Fig. 9. In a Schottky type rectifier device, the $\mathrm{C}-\mathrm{V}$ relation is written as (Rhoderick, 1982, Daş et al., 2021):

$C^{-2}=\frac{2\left(V_{o}+V\right)}{q \varepsilon_{s} A^{2} N_{D}}$ 
herein, $\mathrm{V}_{\mathrm{o}}$ is the built potential at zero bias, $\varepsilon_{\mathrm{s}}$ is the dielectric constant of semiconductor (equal to $11.8 \varepsilon_{0}$ for $\mathrm{Si}$ ), $\mathrm{A}$ is the rectifier contact area, $\mathrm{N}_{\mathrm{D}}$ is the ionized donor density of the n-type semiconductor. From the intercept and slope of the $\mathrm{C}^{-2}-\mathrm{V}$ plot, the $\mathrm{V}_{\mathrm{o}}$ and $\mathrm{N}_{\mathrm{D}}$ is calculated. The $N_{D}$ is obtained by the following equation:

$$
N_{D}=\frac{2}{q \varepsilon_{S} A^{2}}\left[-\frac{1}{d\left(1 / C^{2}\right) / d V}\right]
$$

As the $\Phi_{b}$ is the sum of the $V_{o}$ and $E_{f}$, where $E_{f}$ is the Fermi level and it can be calculated from the equation:

$$
\boldsymbol{E} \boldsymbol{f}=\frac{k T}{q} \ln \left(\frac{N_{C}}{N_{D}}\right)
$$

where $N_{C}$ is the effective density of states in the Si conductance band $\left(N_{C}=2.85 \times 10^{19} \mathrm{~cm}^{-3}\right.$ for $\mathrm{Si}$ at room temperature). Therefore, the $\Phi_{\mathrm{b}}$ can be calculated for each frequency by the following equation:

$$
\Phi_{b}=V_{o}+E_{f}
$$

For non-ideal structures, the equation should be corrected by taking into account of ideality factor (n), as shown below:

$$
\Phi_{b}=\left(V_{o} / n\right)+E_{f}
$$

From the equations, the $\mathrm{V}_{\mathrm{d}}, \mathrm{N}_{\mathrm{d}}, \mathrm{E}_{\mathrm{f}}$, and $\Phi_{\mathrm{b}}$ values of the $\mathrm{rGO} / \mathrm{n}-\mathrm{Si}$ heterojunction device were calculated and tabulated in Table 4. According to the results, it can be said that the mentioned diode parameters $\left(\mathrm{V}_{\mathrm{d}}, \mathrm{N}_{\mathrm{d}}\right.$, and $\Phi_{\mathrm{b}}$ values) are sensible to frequency changes, whereas the $\mathrm{E}_{\mathrm{f}}$ values are independent of the applied frequencies. Also, the different behavior of the $\Phi b$ obtained from the $\mathrm{C}-\mathrm{V}$ and the $\mathrm{I}-\mathrm{V}$ measurement techniques can be explained by inhomogenous distribution of the $\Phi b$ that occur due to the presence of rGO thin film layer at $\mathrm{Au} / \mathrm{n}-\mathrm{Si}$ interface. The inhomogeneties is explained as a combination of the interfacial oxide layer composition, non-uniformity of the interfacial rGO layer thickness, and distribution of interfacial charges. 


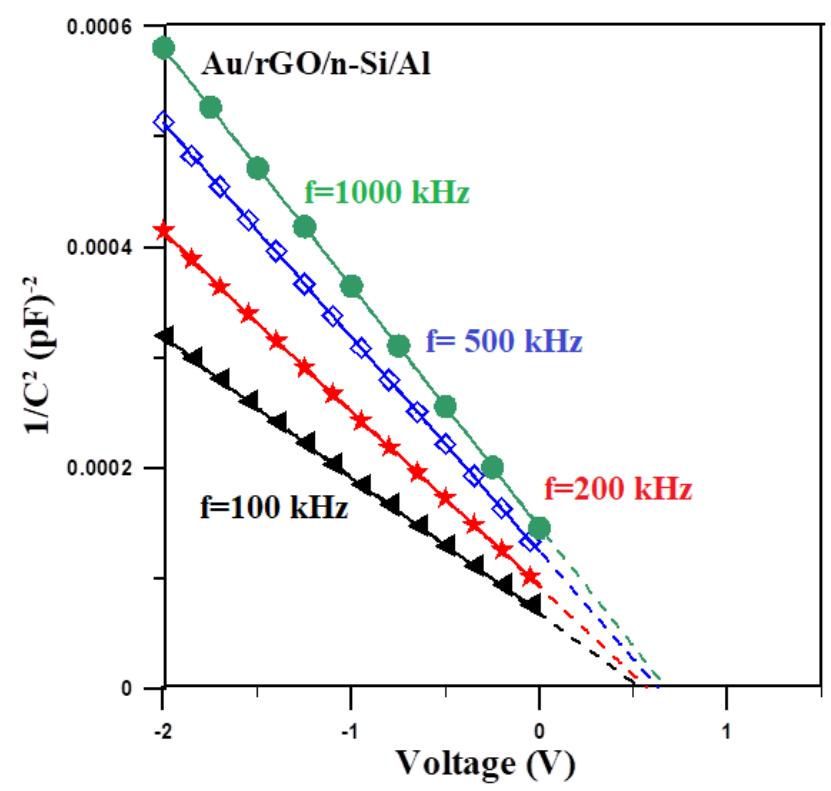

Fig. 9. The $\mathrm{C}^{-2}-\mathrm{V}$ characteristics of the $\mathrm{rGO} / \mathrm{n}-\mathrm{Si}$ heterojunction device for various frequencies.

Table 4. The junction parameters obtained from $\mathrm{C}^{-2}-\mathrm{V}$ plots for the $\mathrm{rGO} / \mathrm{n}-\mathrm{Si}$ device at room temperature.

\begin{tabular}{ccccc}
\hline $\begin{array}{c}\text { Frequency } \\
(\mathbf{k H z})\end{array}$ & $\begin{array}{c}\text { Diffusion } \\
\text { Potential, } \mathbf{V}_{\mathbf{d}} \\
(\mathbf{V})\end{array}$ & $\begin{array}{c}\text { Carrier } \\
\text { Concentration, } \\
\mathbf{N}_{\mathbf{d}}\left(\mathbf{c m}^{-3}\right)\end{array}$ & $\begin{array}{c}\text { Fermi } \\
\mathbf{E n e r g y}, \\
\mathbf{E}_{\mathbf{f}}(\mathbf{e V})\end{array}$ & $\mathbf{\Phi}_{\mathbf{b}}(\mathbf{e V})$ \\
\hline 1000 & 0.68 & $1.56^{*} 10^{15}$ & 0.26 & 0.95 \\
500 & 0.64 & $1.22 * 10^{15}$ & 0.26 & 0.91 \\
200 & 0.58 & $1.00 * 10^{15}$ & 0.26 & 0.84 \\
100 & 0.55 & $0.89 * 10^{15}$ & 0.26 & 0.80 \\
\hline
\end{tabular}

\section{Conclusions}

In summary, this study demonstrates the green synthesis of rGO and device fabrication for optoelectronic applications. In here, GO was oxidized from graphite by the modified Hummers' method while rGO was prepared using LAA as the reducing agent. Subsequently, GO/n-Si and $\mathrm{rGO} / \mathrm{n}-\mathrm{Si}$ heterojunction device fabrications were carried out using the spin coating method. The electrical characteristics of the fabricated heterojunctions were analyzed in detail by using I-V measurements. The obtained main junction parameters showed that the rGO thin film improved device characteristics compared to the GO thin film. In addition, the electrical characteristics of the $\mathrm{rGO} / \mathrm{n}-\mathrm{Si}$ heterojunction were investigated by $\mathrm{I}-\mathrm{V}$ measurements as a function of temperature in the range of $75-300 \mathrm{~K}$. It was seen that the device parameters (such as $n, \Phi_{b}, I_{o} R_{s}$ ) calculated by thermionic emission and Norde methods showed a strong dependence on the applied temperature. Furthermore, C-V measurements of the $\mathrm{rGO} / \mathrm{n}-\mathrm{Si}$ heterojunction demonstrated that the device exhibits capacitive properties in the frequency range of $100-1000 \mathrm{kHz}$. On the other hand, the photoelectrical properties of the $\mathrm{rGO} / \mathrm{n}-\mathrm{Si}$ 
heterojunction device were evaluated under the illumination of intensity $100 \mathrm{mWcm}^{-2}$. All obtained results show that the synthesized rGO material has great potential for application in optoelectronic devices.

\section{Acknowledgement}

The author would like to express the gratefulness to Prof. Dr. Şakir Aydoğan for the material and laboratory support in this research.

\section{References}

A, R.M., Iraqi, A., Aziz, S.B., S, N.A. and Brza, M.A. (2020). "Conducting Polymers for Optoelectronic Devices and Organic Solar Cells: A Review", Polymers (Basel), 12 (11).

Abdel-Khalek, H., El-Samahi, M.I., El Salam, M.A. and El-Mahalawy, A.M. (2018). "Fabrication and performance evaluation of ultraviolet photodetector based on organic /inorganic heterojunction". Current Applied Physics, 18 (12), 1496-1506.

Andrijanto, E., Shoelarta, S., Subiyanto, G., Rifki, S. (2016)." Facile synthesis of graphene from graphite using ascorbic acid as reducing agent". AIP conference proceedings, 1725, 020003.

Asare, J., Agyei-Tuffour, B., Amonoo, E.A., Dodoo-Arhin, D., Nyankson, E., Mensah, B., Oyewole, O.O., Yaya, A., Onwona-Agyeman, B. and Lomonaco, G. (2020). "Effects of substrates on the performance of optoelectronic devices: A review. Cogent Engineering", 7 (1), 1829274.

Bayrakçeken Yurtcan, A. and Daş, E. (2018). "Chemically synthesized reduced graphene oxide-carbon black based hybrid catalysts for PEM fuel cells", International Journal of Hydrogen Energy, 43 (40), 18691-18701.

Bhaumik, A. and Narayan, J. (2019). "Reduced Graphene Oxide-Nanostructured Silicon Photosensors with High Photoresponsivity at Room Temperature", ACS Applied Nano Materials, 2 (4), 2086-2098.

Chang, H. and Wu, H. (2013). "Graphene-based nanocomposites: preparation, functionalization, and energy and environmental applications". Energy \& Environmental Science, 6 (12), 3483.

Chen, L., Liu, W., Su, X., Xiao, S., Xie, H., Uher, C., Tang, X. (2017). "Chemical synthesis and enhanced electrical properties of bulk poly(3,4-ethylenedioxythiophene)/reduced graphene oxide nanocomposites". Synthetic Metals, 229, 65-71.

Choi, W., Lahiri, I., Seelaboyina, R. and Kang, Y.S. (2010). "Synthesis of Graphene and Its Applications: A Review", Critical Reviews in Solid State and Materials Sciences, 35 (1), 52 71.

Choi, Y.J., Woo, H.J., Kim, S., Sun, J., Kang, M.S., Song, Y.J. and Cho, J.H. (2020). "Schottky junction photodiode based on graphene organic semiconductor heterostructure". Journal of Industrial and Engineering Chemistry, 89, 233-238.

Chua, C.K. and Pumera, M. (2014). "Chemical reduction of graphene oxide: a synthetic chemistry viewpoint". Chem Soc Rev, 43 (1), 291-312. 
Çaldıran, Z., Deniz A. R., Şahin, Y., Metin, Ö., Meral, K., Aydoğan, Ş. (2013). "The electrical characteristics of the $\mathrm{Fe}_{3} \mathrm{O}_{4} / \mathrm{Si}$ junctions", Journal of Alloys and Compounds. 552, 437-442.

Çaldıran, Z., (2021). "Modification of Schottky barrier height using an inorganic compound interface layer for various contact metals in the metal/p-Si device structure". Journal of Alloys and Compounds, 865, 158856.

Daş, E., Alkan Gürsel, S., Işikel Şanli, L. and Bayrakçeken Yurtcan, A. (2016). "Comparison of two different catalyst preparation methods for graphene nanoplatelets supported platinum catalysts", International Journal of Hydrogen Energy, 41 (23), 9755-9761.

Daş, E., Orhan, Z., Aydoğan, Ş. and Güzeldir, B. (2021). "Fabrication and characterization of $\mathrm{Al} / \mathrm{n}-\mathrm{Si} / \mathrm{Al}$ schottky diode with rGO interfacial layer obtained by using spin coating method". Materials Today: Proceedings. In press, doi:10.1016/j.matpr.2021.01.554, 46(16), 6899- 6903.

Daş, E., Incekara, U., Aydogan, Ş. (2021). "A comparative study on electrical characteristics of $\mathrm{Ni} / \mathrm{n}-\mathrm{Si}$ and Ni/p-Si Schottky diodes with Pinus Sylvestris Resin interfacial layer in dark and under illumination at room temperature", Optical Materials, 119, 111380.

De Silva, K. K. H., Huang, H. H, Joshi, R. K., Yoshimura, M. (2017). "Chemical reduction of graphene oxide using green reductants", Carbon N Y, 119, 190-199.

Ding, H., Zhang, S., Chen, J. T., Hu, X. P., Du, Z. F., Qiu, Y. X., Zhao, D. L. (2015). "Reduction of graphene oxide at room temperature with vitamin $\mathrm{C}$ for $\mathrm{RGO}-\mathrm{TiO}_{2}$ photoanodes in dyesensitized solar cell", Thin Solid Films 584, 29-36.

Dua, V., Surwade, S. P., Ammu, S., Agnihotra S. R., Jain, S., Roberts, K. E., Park, S., Rouff, R. S., Manohar, S. K. (2010). "All-organic vapor sensor using inkjet-printed reduced graphene oxide", Angew Chemie Int Ed, 49, 2154-2157.

Ertap, H., Kacus, H., Aydogan, S. and Karabulut, M. (2020). "Analysis of temperature dependent electrical characteristics of $\mathrm{Au} / \mathrm{GaSe}$ Schottky barrier diode improved by $\mathrm{Ce}$ doping", Sensors and Actuators A: Physical, 315, 112264.

Fernández-Merino, M. J., Guardia, L., Paredes, J. I. Villar-Rodil, S., Solis-Fernandez, P., Martinez-Alonso, A., Tascon, J. M. D. (2010). "Vitamin C is an ideal substitute for hydrazine in the reduction of graphene oxide suspensions", J. Phys. Chem. C, 114, 6426-6432.

Gao, H. and Duan, H. (2014). "2D and 3D graphene materials: Preparation and bioelectrochemical applications", Biosens Bioelectron, 65C, 404-419.

Ha, H.W., Choudhury, A., Kamal, T., Kim, D.H. and Park, S.Y. (2012). "Effect of chemical modification of graphene on mechanical, electrical, and thermal properties of polyimide/graphene nanocomposites", ACS Appl Mater Interfaces, 4 (9), 4623-30.

Hummers, W.S. and Offeman, R.E. (1958). "Preparation of Graphitic Oxide", J. Am. Chem. Soc., 80, 1339.

Hur, S.H. and Park, J.-N. (2013). "Graphene and its application in fuel cell catalysis: a review". Asia-Pacific Journal of Chemical Engineering, 8 (2), 218-233. 
Im, H. J., Ding, Y., Pelz, J. P., Choyke, W. J. (2001). "Nanometer-scale test of the Tung model of Schottky-barrier height inhomogeneity", Phys. Rev. B. 64, 075310.

Iskandar, F., Hikmah, U., Stavila, E., Aimon A. (2017). "Microwave-assisted reduction method under nitrogen atmosphere for synthesis and electrical conductivity improvement of reduced graphene oxide (rGO)", RSC Adv, 7 (83):52391-52397.

Karabulut, A., Sarilmaz, A., Ozel, F., Orak, İ. and Şahinkaya, M.A. (2020). "A novel device fabricated with $\mathrm{Cu}_{2} \mathrm{NiSnS}_{4}$ chalcogenide: morphological and temperature-dependent electrical characterizations", Current Applied Physics, 20 (1), 58-64.

Kim, C.H. 2018. "Nanostructured Graphene: An Active Component in Optoelectronic Devices", Nanomaterials (Basel), 8 (5).

Liu, Y., Wang, F., Wang, X., Wang, X., Flahaut, E., Liu, X., Li, Y., Wang, X., Xu, Y., Shi, Y. and Zhang, R. (2015). "Planar carbon nanotube-graphene hybrid films for high-performance broadband photodetectors", Nat Commun, 6, 8589.

Mao, S.; Pu, H.; Chen, J. (2012) "Graphene oxide and its reduction: modeling and experimental progress", RSC Advances, 2, 2643-2662.

Nair, R. R., Blake, P., Grigorenko, A. N., Novoselov, K. S., Booth, T. J., Stauber, T., Peres, N. M. R., Geim, A. K. (2008). "Fine structure constant defines visual transparency of graphene", Science, 320, 1308.

Orhan, Z., Cinan, E., Çaldıran, Z., Kurucu, Y. and Daş, E. (2020). "Synthesis of CuO-graphene nanocomposite material and the effect of gamma radiation on $\mathrm{CuO}-$ graphene/p-Si junction diode", Journal of Materials Science: Materials in Electronics, 31 (15), 12715-12724.

Rabchinskii, M. K., Dideikin, A. T., Kirilenko, D. A., Baidakova, M. V., Shnitov, V. V., Roth, F. et. al. (2018). "Facile reduction of graphene oxide suspensions and film using glass wafers", Scientific Reports, 8, 14154.

Rhoderick, E. H. (1982). "Metal-Semiconductor contacts, in:IEE Proc. I. Solid State Electron Device. Doi:10.1049/ip.i.1.1982.0001.

Song, P., Zhang, X., Sun, M., Cui, X., Lin, Y. (2012). "Synthesis of graphene nanosheets via oxalic acid-induced chemical reduction of exfoliated graphite oxide", RSC Advances, 2, 11681173.

Stankovich, S., Dikin, D.A., Piner, R.D., Kohlhaas, K.A., Kleinhammes, A., Jia, Y., Wu, Y., Nguyen, S.T. and Ruoff, R.S. (2007). "Synthesis of graphene-based nanosheets via chemical reduction of exfoliated graphite oxide", Carbon, 45 (7), 1558-1565.

Sui, Z., Zhang, X., Lei, Y., Luo, Y. (2011). "Easy and green synthesis of reduced graphite oxide-based hydrogels", Carbon N Y, 49, 4314-4321.

Tiamduangtawan, P. and Saenboonruang, P. (2019)." Environmental-friendly synthesis of reduced graphene oxide (rGO) using gamma irradiation", Journal of Physics: Conference Series, 1285, 012034. 
Yakuphanoğlu, F. (2010). "Controlling of silicom-insulator-metal junction by organic semiconductor polymer thin film", Synthetic Metals, 160, 1551-1555.

Zheng, F., Xu, W.L., Jin, H. D., Hao, X. T., Ghiggino, P., (2015). "Charge transfer from poly(3hexylthiophene) to graphene oxide and reduced graphene oxide", RSC Advances, 5, 89515.

Zhu, X., Liu, Q., Zhu, X., Li, C., Xu, M. and Liang, Y. (2012). "Reduction of graphene oxide via ascorbic acid and its application for simultaneous detection of dopamine and ascorbic acid", Int. J. Electrochem. Sci, 7, 5172-5184. 